\title{
Technical and economic calculation of a solar- powered charging station for electric vehicles
}

\author{
Hnatov A. ${ }^{1}$, Arhun Shch. ${ }^{1}$, Hnatova H. ${ }^{1}$, Sokhin P. ${ }^{1}$ \\ ${ }^{1}$ Kharkiv National Automobile and Highway University, Ukraine
}

\begin{abstract}
Problem. Development and implementation of green technologies is both an urgent and a cost-effective scientific and engineering task. Therefore, the issues related to the study of renewable energy sources, which are used as the main sources of energy for electric vehicles, are quite relevant and promising. At the same time, an equally important question is how profitable is building solar charging stations in terms of both ecology and economy. Goal. The aim is calculation and analysis of technical and economic indicators of a solar charging station for electric vehicles (EV). Methodology. The analytical methods of studying the development and application of the ways and devices to transform the energy of the sun into electricity are used, as well as the methods of experimental research and mathematical methods of processing and modulation of the received results; methods of calculating technical and economic indicators. Results. The review of the literature on the development of renewable energy sources, in particular, solar power plants, and the spread of electric vehicles with the gradual displacement (replacement) of traditional cars working on internal combustion engines with electric vehicles (BEV and PHEV) was made. The main parameters and technical characteristics of the solar-powered charging station (SPCS) were studied. For the analysis and calculation of technical and economic indicators of SPCS for EV it is offered to take a SPP with a capacity of $20 \mathrm{~kW}$ as a basis. The calculation of SPCS electricity generation both for own consumption and for power supply of EV and the sale of surplus electricity to the general network at the "green tariff" was carried out. Originality. The technical and economic calculation of SCS was made taking into account the rise of electricity prices in Kharkiv region (Ukraine). Practical value. According to the analysis of the obtained results, it can be said that the payback period of SPCS for $E V$ is about 7.9 years. If we consider the constant increase in the cost of electricity (approximately $15 \%$ per year), we can expect the payback after 6.8 years of operation.
\end{abstract}

Key words: solar-powered charging station, green energy, green tariff, solar energy, solar power plant, electric car, energy-efficient technologies, solar panels.

\section{Introduction}

Solar energy is one of the most common branches of renewable energy, which is rapidly developing in Ukraine. This is not surprising, because after the notorious events at the Chernobyl nuclear power plant (Ukraine, 1986) and the Fukushima1 nuclear power plant (Japan, 2011), the world has changed. Along with the desire to abandon the production of electricity from hydrocarbon fuels, humanity has begun to be very wary of nuclear technologies for generating electricity $[1,2]$. Although the generation of electricity at nuclear power plants (NPPs) is caused by the fission of uranium isotope atoms and then by steam and steam turbines, much of the energy generated is converted into electricity, but it is thought that atomic generation of electricity, due to low emissions of carbon, refers to renewable. It is difficult to disagree with this, but we should take into account the fact that uranium is needed to generate electricity by nuclear technology. This metal is heavy, and its reserves on Earth may eventually be depleted. Although, it should be added that this, with the current consumption of uranium fuel in nuclear power plants can happen in hundreds, if not thousands of years. But progress is not standing still, including the one in electricity generation technologies. Thus, it is possible to say with a great probability that by this time new technologies of electricity generation will be created, and they will not have the disadvantages inherent in the existing ones [3 - 5]. 
At the same time, renewable energy is obtained from natural sources that do not cause the release of carbon and are recovered fairly quickly. When it comes to protecting the environment, renewable energy sources are much more efficient than traditional ones, as this way of producing energy leads to reduced greenhouse gas emissions and air pollution. Therefore, in various countries, including Ukraine, various incentives are introduced, such as targeted subsidies, abolition or reduction of the tax burden, etc. [6-8]. According to the Law of Ukraine on Electricity № 575/97-BP of 16.10.1997: "green tariff” is a tariff at which the wholesale electricity market of Ukraine is obliged to purchase electricity produced at electricity facilities from alternative energy sources. In accordance with this law, power which is generated using solar power plants (SPP), wind power plants and hydroelectric power plants is accepted by the general network and paid for by the wholesale electricity market at a "green tariff".

Along with the trend of development and distribution of renewable energy sources, there is a growing interest in new transport, which uses these sources for its operation. This is electric transport, as well as the so-called hydrogen transport, using hydrogen to generate electricity and supply it to its power plant $[5,8,9]$. Therefore, the issues related to the study of renewable energy sources, which are used as the main energy sources for electric vehicles are quite relevant and promising.

\section{Analysis of publications}

As of the end of 2020, 9.9 million electric vehicles (BEV and PHEV) were registered in the world, of which 4.2 million were in China [10]. It is almost $46 \%$ of all Electric Vehicles (EV) in the world. China has held the lead on this indicator since 2010, but it should be said that the gap between the EV market in China and other countries is gradually narrowing. Thus, according to IAA Mobility, the European market, which includes members of the European Free Trade Association (EFTA), in addition to the European Union, accounts for a total of 3.2 million EV. The third place is occupied by the United States with a rate of 1.7 million EV [11]. If we consider European countries separately, Germany ranks the third with a score of 702981 EV. Next are the United Kingdom (447,486 EV), Norway $(433,609$ EV) and France $(413,212 \mathrm{EV})$.

In Ukraine, the market of electric vehicles, as well as the market of renewable (green) energy is only approaching the stage of intensive development. Thus, as of the end of 2020, the Ukrainian market numbered $55051 \mathrm{EV}$, of which there are 25853 BEVs and 29198 PHEVs [12]. According to the Ministry of Internal Affairs of Ukraine, for the period of January-October 2021, the Ukrainian fleet of EV was replenished by 6751 units. This is $11.3 \%$ more than in the same ten months of 2020. So, as with renewable energy, we can see a steady growth of these trends and these technologies. It is quite logical to combine them into a single system, where renewable energy sources are power sources for $\mathrm{EV}$. That is, it is considered relevant and promising to make the charging infrastructure for $\mathrm{EV}$, for example, on the basis of solar power plants, as proposed in [6, $13-18]$.

The authors of article [14] investigate the possibility of charging the batteries of electric vehicles from SPP. At the same time, the SPP operation system is designed in such a way that the charging station always has enough electricity to charge electric vehicles during the day. In [15], similar issues are considered for the territory of India, with an emphasis on the fact that the solar power plant is the main source of electricity for the EV charge. The SPP itself allows you to connect to its electricity storage devices as an alternative source that compensates for the shortage or excess of electricity in the general network. The authors of [16] went further on the path of introducing renewable energy sources into the EV infrastructure. They proposed to combine a solar power plant with a wind turbine. Thus, the generation of electricity for the EV charge occurs simultaneously in two green ways. Also, it should be noted that such a technical solution will ensure the generation of electricity in the dark (provided there is wind). Similar studies are presented in works [8, 17]. Only here the authors proposed to use low-power sources of electricity together with SPP, which convert kinetic energy from pressure into electricity. This approach is quite relevant and promising for the organization of $\mathrm{EV}$ charging infrastructure in large cities. The authors of [18] proposed to make a solar charging station for two types of EV at once - BEV and EV, running on hydrogen fuel. One part of the generated electricity is used to charge $\mathrm{EV}$, and the other part works in aqueous electrolysis to form hydrogen. This provides power to both BEVs and cars, where the main element for the formation of electricity is hydrogen.

So, as was already mentioned, the development of SPP for EV charging infrastructure is an 
urgent issue. And quite naturally there is a need to calculate the economic effect of its implementation. For how long is such a solar charging station able to pass the payback period and reach a net income? Building such power plants that accelerate the transition of transport from internal combustion engines to $\mathrm{EV}$ is expedient not only from the ecological point of view, but also in terms of economy.

The study in this paper is aimed at finding the answers to the questions.

\section{Purpose and Tasks}

The purpose of the work is to calculate and analyze the technical and economic indicators of the solar-powered charging station for electric vehicles.

To achieve this goal, there is a need to solve the following tasks:

- to investigate the basic parameters and technical characteristics of the solar-powered charging station (SPCS);

- to calculate the generation of SPCS electricity both for own consumption and for power supply of EV and the sale to the general network at the "green tariff";

- to carry out technical and economic calculation of SPCS taking into account the rising price of electricity in Ukraine.

\section{Basic parameters and technical characteristics of SPCS}

For the analysis and calculation of technical and economic indicators of SPCS for EV we will take the SPP with a capacity of $20 \mathrm{~kW}$ as a basis. Such capacity, in our opinion, will allow not only to generate enough electricity to charge EV on the territory of Ukraine (Kharkiv region), but also to sell its balance at a "green tariff" to the general network.

The main technical characteristics of SPCS are:

- power of solar panels: $20.72 \mathrm{~kW}$;

- power of the hybrid inverter: $10 \mathrm{~kW}$;

- number of hybrid inverters: 2 pcs.;

- panel power: $280 \mathrm{~W}$;

- number of panels: 74 pcs.;

- number of used Nissan Leaf batteries,

$24 \mathrm{kWh}-4$ pcs.;

- type of panels: polycrystalline;

- location: pitched roof;

- angle of inclination: $34^{\circ}$;

- orientation: south;

- additional load on the roof: $20 \mathrm{~kg} / \mathrm{m}^{2}$;
- area of the solar panels: $126 \mathrm{~m}^{2}$.

\section{Calculation of electricity generation}

The average values of electricity generation by SPCS with a capacity of $20 \mathrm{~kW}$ for the Kharkiv region are given in Table 1 . These data were obtained during the experimental studies of the SPP, which was developed in KhNADU [6].

Table 1. Average values of electricity generation by SPCS with a capacity of $20 \mathrm{~kW}$

\begin{tabular}{|c|c|}
\hline Month & Generation, kWh \\
\hline January & 1020 \\
\hline February & 1280 \\
\hline March & 1920 \\
\hline April & 2380 \\
\hline May & 3080 \\
\hline June & 3100 \\
\hline July & 3020 \\
\hline August & 2900 \\
\hline September & 2280 \\
\hline October & 1580 \\
\hline November & 760 \\
\hline December & 620 \\
\hline Together for a year & 23940 \\
\hline
\end{tabular}

Based on the results of electricity generation, the generation schedule is built, Fig. 1, kWh.

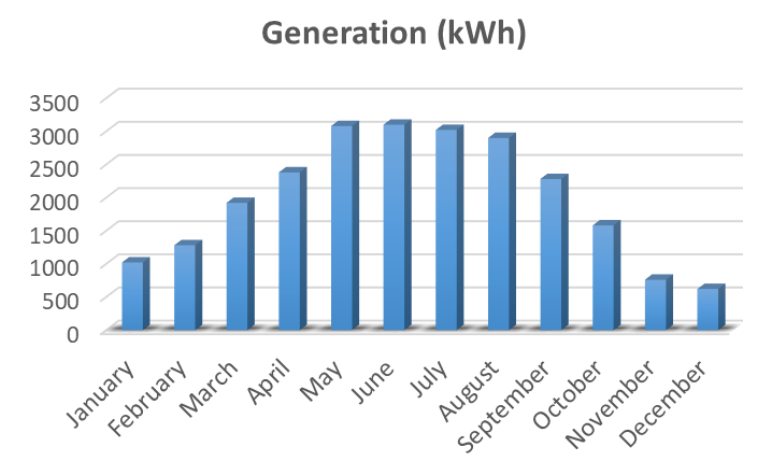

Fig. 1. Schedule of SPCS electricity generation by months

For a more accurate and correct analysis of technical and economic indicators of the proposed SPCS it is necessary to indicate the cost of its main components and the cost of designinstallation and commissioning works.

The cost of the main components of the SPCS is:

- solar battery JA Solar JAP60S01280/SC - 193,866 UAH;

- hybrid inverter Infini Solar $10 \mathrm{~kW}$ - 
104,246 UAH;

- AKB Axioma AX-GEL-100, 100 A·h $12 \mathrm{~W}-236,000 \mathrm{UAH}$;

- mounting structure for solar modules 43,665 UAH.

Total (basic equipment): 577,777 UAH.

Additional and consumables: 10,650 UAH.

Design-installation and commissioning works: 43,000 UAH.

The total cost of the solar-powered charging station is $631,427 \mathrm{UAH}$.

The extended structural scheme of SPCS is given in Fig. 2.

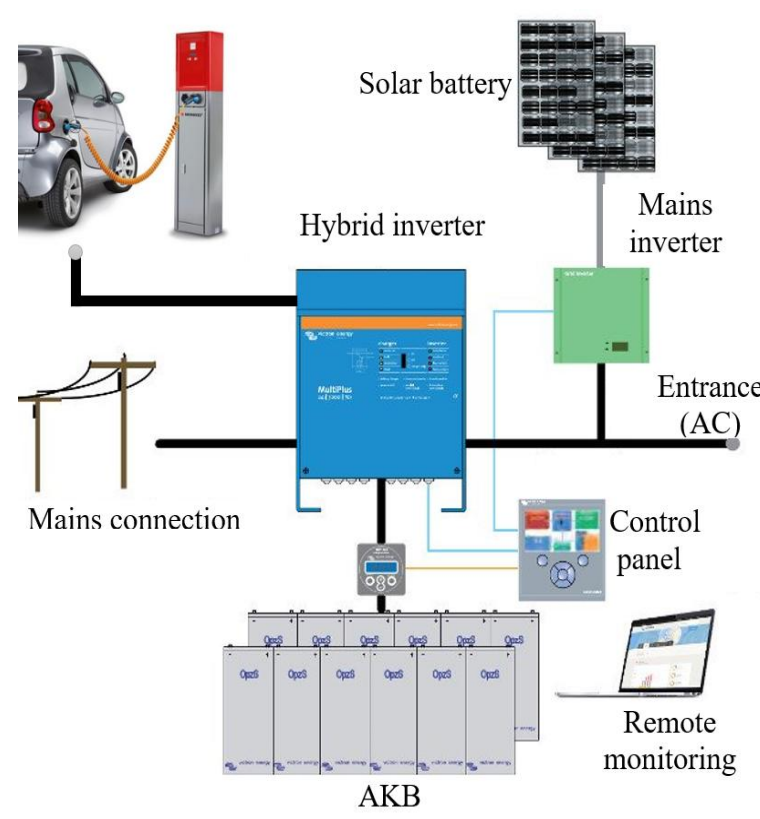

Fig. 2. Structural scheme of SPCS

The service life of the station is the following.

Warranty on solar panels: 10 years. Service life: unlimited.

Warranty on inverter equipment: 5 years. Service life: from 20 to 25 years.

Warranty for installation work: 2 years.
Technical and economic calculation of SPCS

The main parameters of the SPCS, with a capacity of $20 \mathrm{~kW}$ for technical and economic calculation are given in Table 2 .

In accordance with the specified parameters of the SPCS operation (see Table 2), the technical and economic calculation was carried out in accordance with each month of its operation. The main indicators of technical and economic calculation are summarized in Table 3.

Table 2. Parameters of SPCS operation for technical and economic calculation

\begin{tabular}{|l|c|l|}
\hline $\begin{array}{l}\text { Parameter / characteris- } \\
\text { tic }\end{array}$ & Quantity & \multicolumn{1}{|c|}{$\begin{array}{c}\text { Dimen- } \\
\text { sionality }\end{array}$} \\
\hline $\begin{array}{l}\text { Own consumption per } \\
\text { month }\end{array}$ & 150 & $\mathrm{kWh} / \mathrm{month}$ \\
\hline $\begin{array}{l}\text { The cost of electricity } \\
\text { per 1 kWh }\end{array}$ & 168 & $\mathrm{kop}$ \\
\hline Green tariff rate & 420 & $\mathrm{kopecks} / \mathrm{kWh}$ \\
\hline $\begin{array}{l}\text { The amount of electrici- } \\
\text { ty to be sold to charge } \\
\text { electric vehicles per } \\
\text { month }\end{array}$ & 300 & $\mathrm{kWh} / \mathrm{month}$ \\
\hline $\begin{array}{l}\text { Electric vehicle charge } \\
\text { rate for } 1 \mathrm{kWh}\end{array}$ & 600 & $\mathrm{kop}$ \\
\hline
\end{tabular}

The "green tariff" in Ukraine is:

- until December 31, 2019 499.27 kopiykas;

- from January 1, 2020 to December 31, 2024 - 420 kopiykas;

- from January 1, 2025 to December 31, 2029 - 368 kopiykas.

Taking into account the change in the "green tariff", we will calculate the financial performance of SPCS for the first 15 years of its operation, Table 4.

When calculating, we assume that, on average, $300 \mathrm{kWh}$ of generated electricity each month will be spent on charging electric vehicles at a rate of 600 kopiykas for $1 \mathrm{kWh}$, Table 2 .

Table 3. The main indicators of technical and economic calculation of SPCS operation for 2020

\begin{tabular}{|l|c|c|c|c|c|c|c|c|}
\hline Month & $\begin{array}{c}\text { Generation, } \\
\mathrm{kWh}\end{array}$ & $\begin{array}{c}\text { Own } \\
\text { consumption, } \\
\mathrm{kWh}\end{array}$ & $\begin{array}{c}\text { Charge of } \\
\text { electric } \\
\text { cars, kWh }\end{array}$ & $\begin{array}{c}\text { Income } \\
\text { from } \\
\text { charge, } \\
\text { UAH }\end{array}$ & $\begin{array}{c}\text { Sale in a } \\
\text { network, } \\
\mathrm{kWh}\end{array}$ & $\begin{array}{c}\text { Sales } \\
\text { revenue, } \\
\text { UAH }\end{array}$ & $\begin{array}{c}\text { Tax } \\
19.5 \%\end{array}$ & $\begin{array}{c}\text { Profit } \\
\text { from } \\
\text { sale, } \\
\text { UAH }\end{array}$ \\
\hline January & 1020 & 150 & 300 & 1800 & 570 & 2394 & 817.83 & 3376.17 \\
\hline February & 1280 & 150 & 400 & 2400 & 730 & 3066 & 1065.87 & 4400.13 \\
\hline March & 1920 & 150 & 400 & 2400 & 1370 & 5754 & 1590.03 & 6563.97 \\
\hline April & 2380 & 150 & 400 & 2400 & 1830 & 7686 & 1966.77 & 8119.23 \\
\hline May & 3080 & 150 & 400 & 2400 & 2530 & 10626 & 2540.07 & 10485.93 \\
\hline June & 3100 & 150 & 480 & 2880 & 2470 & 10374 & 2584.53 & 10669.47 \\
\hline
\end{tabular}




\begin{tabular}{|l|c|c|c|c|c|c|c|c|}
\hline \multicolumn{1}{|c|}{ Month } & $\begin{array}{c}\text { Generation, } \\
\mathrm{kWh}\end{array}$ & $\begin{array}{c}\text { Own } \\
\text { consumption, } \\
\mathrm{kWh}\end{array}$ & $\begin{array}{c}\text { Charge of } \\
\text { electric } \\
\text { cars, } \mathrm{kWh}\end{array}$ & $\begin{array}{c}\text { Income } \\
\text { from } \\
\text { charge, } \\
\mathrm{UAH}\end{array}$ & $\begin{array}{c}\text { Sale in a } \\
\text { network, } \\
\mathrm{kWh}\end{array}$ & $\begin{array}{c}\text { Sales } \\
\text { revenue, } \\
\text { UAH }\end{array}$ & $\begin{array}{c}\text { Tax } \\
19.5 \%\end{array}$ & $\begin{array}{c}\text { Profit } \\
\text { from } \\
\text { sale, } \\
\text { UAH }\end{array}$ \\
\hline July & 3020 & 150 & 480 & 2880 & 2390 & 10038 & 2519.01 & 10398.99 \\
\hline August & 2900 & 150 & 480 & 2880 & 2270 & 9534 & 2420.73 & 9993.27 \\
\hline September & 2280 & 150 & 400 & 2400 & 1730 & 7266 & 1884.87 & 7781.13 \\
\hline October & 1580 & 150 & 400 & 2400 & 1030 & 4326 & 1311.57 & 5414.43 \\
\hline November & 760 & 150 & 400 & 2400 & 210 & 882 & 639.99 & 2642.01 \\
\hline December & 620 & 150 & 300 & 1800 & 170 & 714 & 490.23 & 2023.77 \\
\hline $\begin{array}{l}\text { Together } \\
\text { for a year }\end{array}$ & 23940 & 1800 & 4840 & 29040 & 17300 & 72660 & 19831.5 & $\mathbf{8 1 8 6 8 . 5}$ \\
\hline
\end{tabular}

In accordance with the calculations, it can be noted that the payback period of SPCS for electric vehicles is about 7.9 years, Fig. 3. If we take into account the constant increase in the cost of electricity (approximately $15 \%$ per year), we can expect the payback somewhere in 6.8 years of its operation.

Table 4. Financial indicators of SPCS by years

\begin{tabular}{|c|c|c|c|c|}
\hline & Profit, UAH & Payback, UAH & Profit, UAH & $\begin{array}{c}\text { Payback taking into account the } \\
\text { rise in price of electricity, UAH }\end{array}$ \\
\hline 1 year & 81868.5 & -549558.5 & 94148.775 & -537278 \\
\hline 2 years & 81868.5 & -467690 & 94148.775 & -443129 \\
\hline 3 years & 81868.5 & -385821.5 & 94148.775 & -348981 \\
\hline 4 years & 81868.5 & -303953 & 94148.775 & -254832 \\
\hline 5 years & 81868.5 & -222084.5 & 94148.775 & -160683 \\
\hline 6 years & 74626.72 & -147457.78 & 85820.728 & -74862.4 \\
\hline 7 years & 74626.72 & -72831.06 & 85820.728 & 10958.33 \\
\hline 8 years & 74626.72 & 1795.66 & 85820.728 & 96779.06 \\
\hline 9 years & 74626.72 & 76422.38 & 85820.728 & 182599.8 \\
\hline 10 years & 74626.72 & 151049.1 & 85820.728 & 323820.5 \\
\hline 11 years & 48242.2 & 199291.3 & 55478.53 & 436877.6 \\
\hline 12 years & 98242.2 & 297533.5 & 112978.53 & 549856.1 \\
\hline 13 years & 98242.2 & 395775.7 & 112978.53 & 662834.6 \\
\hline 14 years & 98242.2 & 494017.9 & 112978.53 & 775813.2 \\
\hline 15 years & 98242.2 & 592260.1 & 112978.53 & \\
\hline
\end{tabular}

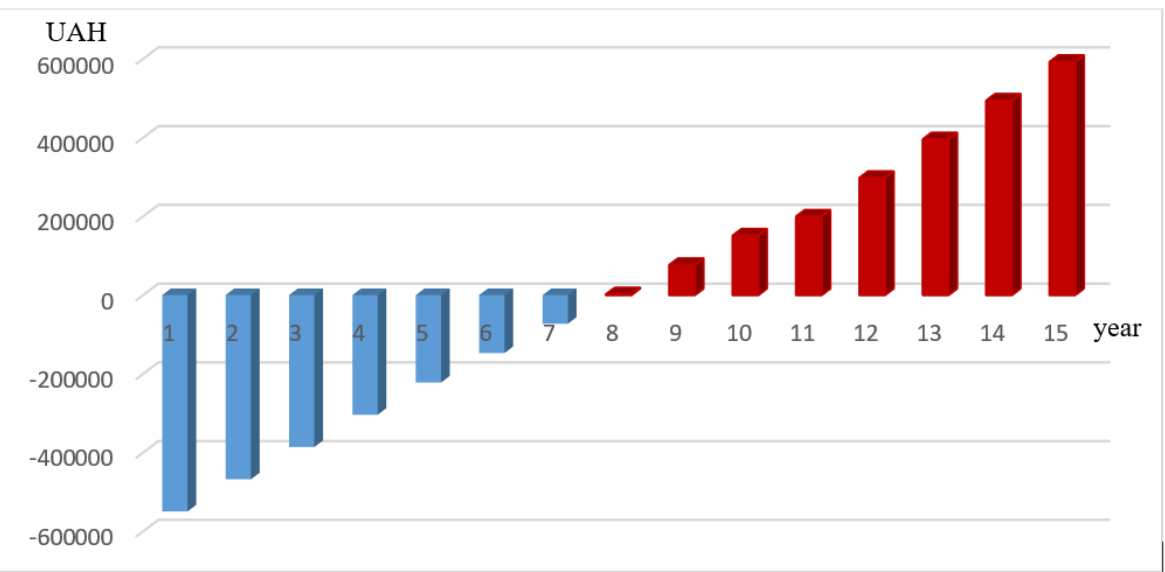

Fig. 3 Efficiency of SPP without taking into account the rise of electricity prices 


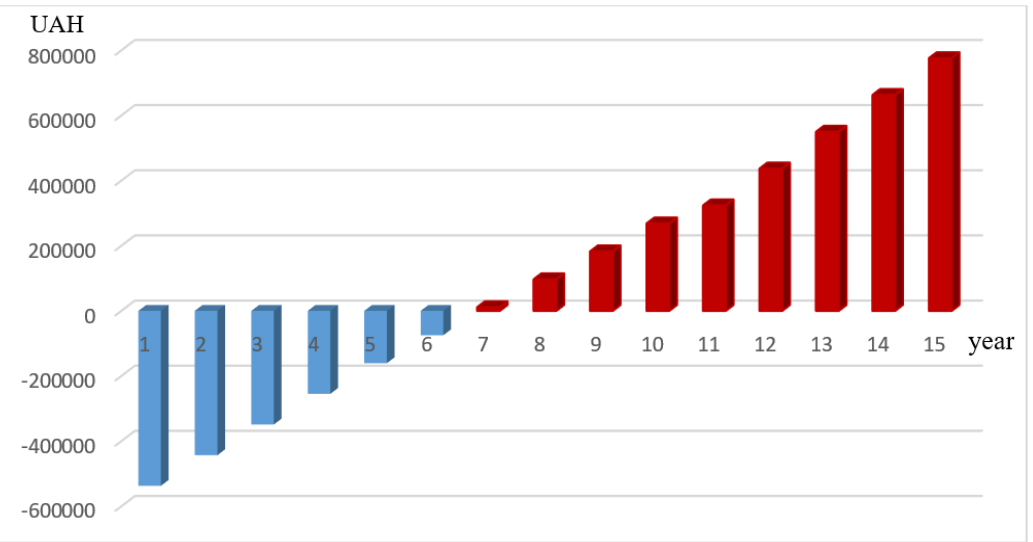

Fig. 4. The efficiency of SPP taking into account the rise of electricity prices

Every year the number of electric cars in Ukraine will increase, as is noted in sources [11 -13]. Therefore, along with this growth, there will be a demand for electricity for their charge and for the corresponding charging infrastructure. So, it is possible to predict with high probability that in the year of termination of the "green tariff" (11 years on schedule, Fig. 4) another charging station for electric vehicles worth 50,000 UAH will be purchased, Fig. 2. This will allow all the generated electricity to be spent on the EV charge. Thus, the cost of purchasing another charger stipulates the payback downfall this year.

\section{Conclusion}

In the course of work, a review of literature sources on the development of renewable energy sources, in particular, solar power plants, was conducted. The trends in the proliferation of electric vehicles with the gradual displacement (replacement) of traditional ICE cars with electric vehicles (BEV and PHEV) were also studied. It is obvious that electric transport requires the development of appropriate charging infrastructure for its operation. Therefore, the development of SPCS for EV is an urgent issue. Quite naturally there is a need to calculate the economic effect of the introduction of SPCS for $\mathrm{EV}$, the benefit of constructing such SPCSs not only in ecology terms, but also in terms of economy. Their development, in its turn, accelerates the transition from traditional transport with internal combustion engines to EVs.

In the framework of this paper, the main parameters and technical characteristics of the SPCS were studied. For the analysis and calculation of technical and economic indicators of SPCS for EV it was offered to take the SPP with a capacity of $20 \mathrm{~kW}$ as a basis.

The calculation of SPCS electricity genera- tion for both own consumption and for EV supply and sale of surplus electricity to the general grid at the "green tariff" was made.

The technical and economic calculation of SPCS was performed taking into account the rise of electricity prices in Ukraine. According to the analysis of the obtained results, it can be noted that the payback period of SPCS for EV is about 7.9 years. If we consider the constant increase in the cost of electricity (approximately $15 \%$ per year), we can expect the payback after about 6.8 years of its operation.

\section{Conflict of interests}

The authors declare that there is no conflict of interests regarding the publication of this paper.

\section{References}

1. Moiseeva, E. M., Tatarinov, V. V., \& Dutov, A. S. (2021, September). Tree of scenarios for the 2011 accident at the first power unit of the Fukushima-1 nuclear power plant. In IOP Conference Series: Earth and Environmental Science. 864 (1), 012045.

2. Akçay, N. (2021). On the 30th anniversary of the Chernobyl Nuclear Power Plant Accident, asSPPsment of the activity concentrations and the radiological hazard parameters of soil samples collected from Rize province and districts. Applied Radiation and Isotopes, 168, 109435.

3. Mostafaeipour, A., Bidokhti, A., Fakhrzad, M. B., Sadegheih, A., \& Mehrjerdi, Y. Z. (2022). A new model for the use of renewable electricity to reduce carbon dioxide emissions. Energy, 238, 121602.

4. Гнатов, А. В., Аргун, Щ. В., Киценко, О. Р. (2017) Умные дороги, как основа ресурсосберегающих технологий в транспортной инфраструктуре. Вісник ПДТУ. Cер.: Технічні науки. 35. 245-252. Gnatov A. V., Argun Sch. V., Kitsenko O. R. (2017) Umnyie dorogi, kak osnova resursosberegayuschih tehnologiy $\mathrm{v}$ transportnoy 
infrastrukture. [Smart Roads as a Basis for Resource-Saving Technologies in Transport Infrastructures] VIsnik PDTU. Ser.: Tekhnichni nauky. 35. 245-252. [in Russian]

5. Hnatov, A., Arhun, S., \& Ponikarovska, S. (2017). Energy saving technologies for urban bus transport. International journal of automotive and mechanical engineering, 14, 4649-4664. doi: https://doi.org/10.15282/ijame.14.4.2017.5.0366.

6. Гнатов, А. В., Аргун, Щ. В., Гнатова, Г. А., \& Тарасов, К. С. (2020). Сонячна зарядна електростанція-комплекс для проведення лабораторних та практичних занять. Vehicle and electronics. Innovative technologies, (17), 19-19. Hnatov, A. V., Arhun, Shch. V., Hnatova, H. A., \& Tarasov, K. S. (2020). Soniachna zariadna elektrostantsiia-kompleks dlia provedennia laboratornykh ta praktychnykh zaniat. [Solar charging power plant-complex for laboratory and practical clasSPP.] Vehicle and electronics. Innovative technologies, (17), 19-19. DOI: $\quad$ https://doi.org/10.30977/VEIT.22269266.2020.17.0.19.

7. Hnatov, A., Shch, A., \& Ulyanets, O. (2018). ESTeT-new innovative specialty for Master students. Автомобильньй транспорт, (42). 103-110.

8. Hnatov, A., Patlins, A., Arhun, S., Kunicina, N., Hnatova, H., Ulianets, O., \& Romanovs, A. Development of an unified energy-efficient system for urban transport. In 2020 6th IEEE International Energy Conference (ENERGYCon). 248-253.

https://ieeexplore.ieee.org/document/9236606

9. Hnatov, A., Patlins, A., Arhun, S., Kunicina, N., Hnatova, H., Ulianets, O., \& Romanovs, A. Development of an unified energy-efficient sys-tem for urban transport. In 2020 6th IEEE International Energy Conference (ENER-GYCon) (pp. 248-253). IEEE. https://ieeexplore.ieee.org/document/9236606.

10. Аналітики порахували кількість електромобілів у світі: Майже половина з них - 8 Kumaï. (2021, May 7). Autogeek. https://autogeek.com.ua/analityky-porakhuvalykilkist-elektromobiliv-u-sviti-majzhe-polovyna-znykh-v-kytai/ Analityky porakhuvaly kilkist elektromobiliv u sviti: Maizhe polovyna z nykh v Kytai. [Analysts have counted the number of electric cars in the world: Almost half of them - in China.] (2021, May 7). Autogeek. https://autogeek.com.ua/analityky-porakhuvalykilkist-elektromobiliv-u-sviti-majzhe-polovyna-znykh-v-kytai/ [in Ukrainian]

11. First global e-mobility ranking-IAA Mobility. (n.d.). Retrieved November 24, 2021, from https://www.iaa.de/en/mobility/newsroom/press/p ress-releaSPP/first-global-e-mobility-ranking
12. Компанія IRS Group. Маркетингові Дослідження Споживачів. CATI, ФокусГруппи, Таємний Покупець.[:En] IRS Group Company. Market Research Consumers.CATI ReSearch, Mystery Shopping. Retrieved November 24, 2021, from http://irsgroup.com.ua/

13. Гнатов, А. В., \& Аргун, Щ. В. (2017). Аналіз схем сонячних електростанцій на фотоелектричних модулях для зарядних станцій електромобілів. Автомобильный транспорт, (41). 163-169.

14. Badea, G., Felseghi, R. A., Varlam, M., Filote, C., Culcer, M., Iliescu, M., \& Răboacă, M. S. (2019). Design and simulation of romanian solar energy charging station for electric vehicles. Energies, 12(1), 74.

15. Vikas, K. S., Reddy, B. R., Abijith, S. G., \& Sindhu, M. R. (2019, April). Controller for charging electric vehicles at workplaces using solar energy. In 2019 International Conference on Communication and Signal Processing (ICCSP) 0862-0866.

16. Chellaswamy, C., Nagaraju, V., \& Muthammal, R. (2018). Solar and wind energy based charging station for electric vehicles. International Journal of Advanced Research in Electrical, Electronics and Instrumentation Engineering, 7(1), 313-324.

17. Arhun, S., Hnatov, A., Mygal, V., Khodyriev, S., Popova, A., \& Hnatova, H. (2020, April). An Integrated System of Alternative Sources of Electricity Generation for Charging Urban Electric BuSPP. In 2020 IEEE 40th International Conference on Electronics and Nanotechnology (ELNANO). 619-624.

18. Mehrjerdi, H. (2019). Off-grid solar powered charging station for electric and hydrogen vehicles including fuel cell and hydrogen storage. International journal of hydrogen Energy, 44(23), 11574-11583.

Hnatov Andrii ${ }^{1}$, professor, Doct. of Science, Head of Vehicle Electronics Department, tel. +38 066-7438-0887, kalifus76@gmail.com, ORCID: https://orcid.org/0000-0003-0932-8849

Shchasiana Arhun ${ }^{1}$, professor, Doct. of Science, Vehicle Electronics Department, shasyana@gmail.com,

ORCID: https://orcid.org/0000-0001-6098-8661

Hnatova Hanna ${ }^{\mathbf{1}}$, student of the Automobile Faculty, tel.+38 0990679809,

e-mail: hannahnatova@gmail.com,

ORCID: https://orcid.org/0000-0001-7263-3024

Sokhin Pavlo ${ }^{1}$, postgraduate, Vehicle Electronics Department, tel. +38 0633473433, info@elektrocar.com.ua,

ORCID: https://orcid.org/0000-0002-2823-2239 
${ }^{1}$ Kharkov National Automobile and Highway University, 25, Yaroslava Mudrogo str., Kharkiv, 61002, Ukraine.

Техніко-економічний розрахунок сонячної зарядної станції для електромобілів

Анотація. Проблема. Розробка та впровадження зелених технологій $\epsilon$ не тільки актуальною, а й економічно вигідною науковою та інженерною задачею. Тому питання пов'язані з дослідженням роботи поновлювальних джерел енергії, які використовуються як основні джерела енергії для електротранспорту $\epsilon$ достатньо актуальними та перспективними. Разом з ичи, не менш актуальним питанням $\epsilon$ наскільки вигідно не лише з екологічної точки зору, а й з економічної розбудовувати сонячні зарядні станції? Мета. Розрахунок та аналіз техніко-економічних показників сонячної зарядної станиії для електромобілів (ЕV). Методологія. Використані аналітичні методи дослідження $з$ розробки та застосування методів та пристроїв для перетворення енергї сонця на електричну. Використано методи експериментальних досліджень та математичні методи обробки та модулювання отриманих результатів. Методи розрахунку техніко-економічних показників. Результати. Проведено огляд літературних джерел щзодо розвитку поновлювальних джерел енергії, зокрема, сонячних електростанцій, та поширенню електромобілів з поступовим витісненням (заміною) традиційних автомобілів з ДВЗ електромобілями (BEV and PHEV). Проведено дослідження основних параметрів та технічних характеристики сонячної зарядної станиіï (СЗС). Для проведення аналізу та розрахунку техніко-економічних показників СЗС для EV запропоновано взяти за основу СЕС потужністю $20 \mathrm{\kappa Bm}$. Проведено розрахунок генеращії електроенергії СЗС як для власного споживання, так $і$ для живлення EV та продажу надлишку електроенергії у загальну мережу за «зеленим тарифом». Орихінальність. Проведено техніко-економічний розрахунок СЗС 3 урахуванням подорожчання електроенергї на території Харківської області (Україна). Практичне значення. За аналізом отриманих результатів можна зазначити, щзо термін окупності СЗС для EV складає близько 7,9 років. Якщзо врахувати постійне зростання вартості електроенергії (приблизно на $15 \%$ в рік), то можна очікувати, що окупність настане на 6,8 роичі ї̈ експлуатайї.

Ключові слова: сонячна зарядна електростанція, зелена енергетика, зелений тариф, сонячна енергетика, сонячна електростаниія, електромобіль, енергоефективні технології, сонячні панелі.

Гнатов Андрій Вікторович ${ }^{1}$, д.т.н., проф. каф. автомобільної електроніки, тел. +38 06674380887 , kalifus76@gmail.com,

ORCID: https://orcid.org/0000-0003-0932-8849

Аргун Щасяна Валіковна ${ }^{1}$, к.т.н., доц. каф. автомобільної електроніки, тел. +38 0993780451, shasyana@gmail.com,

ORCID: https://orcid.org/0000-0001-6098-8661

Гнатова Ганна Андріївна ${ }^{1}$, студент автомобільного факультету ХНАДУ, тел. +38 0990679809 , annagnatova22@gmail.com,

ORCID: https://orcid.org/0000-0001-7263-3024

Сохін Павло Андрійович ${ }^{1}$, аспірант кафедри автомобільної електроніки, тел. +38 0633473433, info@elektrocar.com.ua,

ORCID: https://orcid.org/0000-0002-2823-2239

${ }^{1}$ Харківський національний автомобільнодорожній університет, 61002, Україна, м. Харків, вул. Ярослава Мудрого, 25. 